medRxiv preprint doi: https://doi.org/10.1101/2020.03.21.20037267; this version posted March 30, 2020. The copyright holder for this

preprint (which was not certified by peer review) is the author/funder, who has granted medRxiv a license to display the preprint in

It is made available under a CC-BY-NC-ND 4.0 International license .

\title{
Effect of SARS-CoV-2 infection upon male gonadal function: A single center-
} based study

Ling $\mathrm{Ma}^{\# 1}$, Wen Xie ${ }^{\# 2,5}$, Danyang $\mathrm{Li}^{1}$, Lei Shi ${ }^{1}$, Yanhong Mao ${ }^{1}$, Yao Xiong ${ }^{1}$, Yuanzhen Zhang $^{* 1,3,4}$, Ming Zhang ${ }^{* 1,3}$.

1 Reproductive Medicine Center, Zhongnan Hospital, Wuhan University, Wuhan 430071, Hubei Province, P. R. China.

${ }^{2}$ Department of Laboratory Medicine, Zhongnan Hospital, Wuhan University, Wuhan 430071, Hubei Province, P. R. China.

${ }^{3}$ Hubei Clinical Research Center for Prenatal Diagnosis and Birth Health, Wuhan 430071, Hubei Province, P. R. China.

${ }^{4}$ Department of Obstetrics \& Gynecology, Zhongnan Hospital, Wuhan University, Wuhan 430071, Hubei Province, P. R. China.

${ }^{5}$ Department of Laboratory Medicine, Wuhan Leishenshan Hospital, Wuhan 430071, Hubei Province, P. R. China.

* Corresponding author(s):

Yuanzhen Zhang, E-mail: zhangyuanzhen@,vip.sina.com, Address: No. 169, East Lake Road, Wuhan 430071, Hubei, China. Phone: 86-18907139066; Fax: 86-27-67813009 Ming Zhang, e-mail: whu_mz@163.com, Address: No. 169, East Lake Road, Wuhan 430071, Hubei, China. Phone: 86-15207119991; Fax: 86-27-83746960

\#Equal contribution

\section{Contributions:}

Yuanzhen Zhang and Ming Zhang contributed substantially to the study design, and Ming Zhang also participated in manuscript draft and revision. Ling Ma was in charge of manuscript draft. Wen Xie took responsibility for samples processing and laboratory tests. Danyang Li helped in hormones detection. Lei Shi, Yao Xiong and Yanhong Mao were in charge of data collection and analysis. 
medRxiv preprint doi: https://doi.org/10.1101/2020.03.21.20037267; this version posted March 30, 2020. The copyright holder for this

preprint (which was not certified by peer review) is the author/funder, who has granted medRxiv a license to display the preprint in

It is made available under a CC-BY-NC-ND 4.0 International license .

\title{
Funding Information:
}

Health Commission of Hubei Province scientific research project (No. WJ2019Q048 to M.Z.)

\section{Conflict of interest:}

We declare no conflict of interest.

\begin{abstract}
Since SARS-CoV-2 infection was first identified in December 2019, it spread rapidly and a global pandemic of COVID-19 has occurred. ACE2, the receptor for entry into the target cells by SARS-CoV-2, was found to abundantly express in testes, including spermatogonia, Leydig and Sertoli cells. However, there is no clinical evidence about whether SARS-CoV-2 infection can affect male gonadal function so far. In this study, we compared the sex-related hormones between 81 reproductive-aged men with SARS-CoV-2 infection and 100 age-matched healthy men, and found that serum luteinizing hormone $(\mathrm{LH})$ was significantly increased, but the ratio of testosterone (T) to $\mathrm{LH}$ and the ratio of follicle stimulating hormone (FSH) to $\mathrm{LH}$ were dramatically decreased in males with COVID-19. Besides, multivariable regression analysis indicated that c-reactive protein (CRP) level was significantly associated with serum T:LH ratio in COVID-19 patients. This study provides the first direct evidence about the influence of medical condition of COVID-19 on male sex hormones, alerting more attention to gonadal function evaluation among patients recovered from SARSCoV-2 infection, especially the reproductive-aged men.
\end{abstract}

Key words: SARS-CoV-2, COVID-19, male gonadal function, sex-related hormones, reproductive system 
medRxiv preprint doi: https://doi.org/10.1101/2020.03.21.20037267; this version posted March 30, 2020. The copyright holder for this preprint (which was not certified by peer review) is the author/funder, who has granted medRxiv a license to display the preprint in It is made available under a CC-BY-NC-ND 4.0 International license .

\section{Introduction}

Since the first report in Wuhan in December 2019, a novel coronavirus-induced pneumonia (called COVID-19 by WHO) spread rapidly and triggered a global pandemic outbreak ${ }^{[1]}$. COVID-19 is caused by a previously unknown beta-coronavirus which is now named SARS-CoV-2 due to its high sequence similarity $(\sim 80 \%)$ with SARS-CoV ${ }^{[2]}$. Except for the respiratory symptoms such as cough, fever and even acute respiratory failure, evidences of SARS-CoV-2 attack to multiple organs such as digestive, cardiovascular, urinary systems have been reported [3-5]. Angiotensinconverting enzyme 2 (ACE2) is considered as the receptor for binding and entry into host cells by SARS-CoV-2 ${ }^{[6-7]}$. Theoretically, any cells expressing ACE2 may be susceptible to SARS-CoV-2 infection. According to the online database The Human Protein Atlas portal, testes shows the highest expression level of ACE2 protein and mRNA in the body ${ }^{[8]}$. Based on scRNA-seq profiling of human testes, Wang ZP et al. also reported that ACE2 is predominantly enriched in spermatogonia, Leydig and Sertoli cells ${ }^{[9]}$. All the findings suggest the potential risk of male gonad to be vulnerable to SARS-CoV-2 attack.

In the condition of viremia, virus may shed into the male reproductive track because the blood-testes barrier is not perfect enough to completely isolate virus ${ }^{[10]}$. A wide breath of viruses, such as Zika, Ebola, Marburg viruses, etc. have been found in male testes and semen ${ }^{[11]}$. Virus-induced testes damage can impair gonadal hormone secretion and spermatogenesis, as seen in HIV or mumps-induced orchitis ${ }^{[12]}$. Previous study on SARS suggested the SARS-CoV can cause orchitis ${ }^{[13]}$. However, there is no clinical evidence about whether SARS-CoV-2 infection can affect male gonadal function so far. In this study, we compared the sex-related hormones between reproductive-aged men with SARS-CoV-2 infection and age-matched healthy men, and found serum luteinizing hormone $(\mathrm{LH})$ was significantly increased, but the ratio of testosterone (T) to $\mathrm{LH}$ and the ratio of follicle stimulating hormone $(\mathrm{FSH})$ to $\mathrm{LH}$ were dramatically decreased in male with COVID-19. This study provides the first direct evidence about the influence of medical condition of COVID-19 on male sex hormones, alerting more attention to gonadal function evaluation among patients recovered from 
SARS-CoV-2 infection, especially the reproductive-aged men.

\section{Methods}

\section{Study design and patients}

We performed a retrospective study involving 81 male patients with COVID-19 as the study group, who were hospitalized in Wuhan Leishenshan Hospital from Mar 5 to Mar 18, 2020. All cases were laboratory-confirmed as SARS-CoV-2 positive using quantitative RTPCR (qRT-PCR) on nasal and pharyngeal swab specimens. The diagnosis of COVID-19 and the severity was determined according to the New Coronavirus Pneumonia Prevention and Control Program (7th edition) published by the National Health Commission of China. Briefly, the mild type was defined as "having malaise only without positive chest radiologic findings"; the moderate type was defined as "having common respiratory infection symptoms such as fever, cough and positive chest radiologic changes"; the severe type was determined if any of the following conditions existed, including dyspnea (respiratory rate $\geq 30$ per minute), low finger oxygen saturation $(\leq 93 \%$ at rest), low $\mathrm{PaO} 2 / \mathrm{FiO} 2(\leq 300 \mathrm{mmHg})$ or rapid progress of chest radiological abnormality ( $>50 \%$ within $24-48$ hours); and the critical type was determined if respiratory failure (mechanical ventilation needed), shock or multiple organ dysfunctions was complicated.

All patients aged from 20 54 years (with a median of $38 \mathrm{yrs}$ ). After finishing laboratory tests required for the routine medical purposes, the residual serum samples were collected for male hormone profiles detection. The control group came from the population who previously received reproductive function evaluation and were classified as having normal fertility. 100 age-matched healthy men were randomly selected and the data of their sex-related hormones were collected.

This study was reviewed and approved by the Medical Ethical Committee of Zhongnan Hospital of Wuhan University (approval number 2020033). The residual serum samples used in this study were usually discarded as a medical waste otherwise. And we didn't directly contact with the patients and exert no burden or harm on them. Therefore, written informed consent was waived. 
medRxiv preprint doi: https://doi.org/10.1101/2020.03.21.20037267; this version posted March 30, 2020. The copyright holder for this

preprint (which was not certified by peer review) is the author/funder, who has granted medRxiv a license to display the preprint in

It is made available under a CC-BY-NC-ND 4.0 International license .

\section{Sex-related hormone assessment}

In the study group, serum testosterone $(T)$, estradiol $\left(E_{2}\right)$, progesterone $(P)$, prolactin (PRL), luteinizing hormone (LH), follicle stimulating hormone (FSH), antimullerian hormone (AMH) were detected by electrochemiluminescent immunoassays according to the instructions from the manufacturer (cobas e411, Roche, Switzerland). In the control group, the data of serum T, $E_{2}$, PRL, FSH and LH levels were retrieved from the dataset already kept in our reproductive medical center. The ratio of T:LH, T: $\mathrm{E}_{2}$ and FSH:LH were also calculated.

\section{Statistical analysis}

All statistical analysis was performed using Graphpad Prism 6.04 (San Diego, USA) and SPSS 16.0 (Chicago, IL, USA). Continuous variables were expressed as means \pm standard deviations (SD) or medians and interquartile ranges (IQR) as appropriate. Categorical variables were summarized as the counts and percentages (\%). The distribution of data was analyzed by Kologorov-Smirov test. Differences between two groups were analyzed by Student's t test (parametric) or Mann-Whitney U test (nonparametric). Univariable and multivariable linear regression were performed to analyze the relationship between serum T:LH ratio and the clinical characteristics of the COVID-19 patients. Only the variables showing statistical significance in univariable analysis were included in the multivariable analysis. Statistical significance was defined as $p$ values of $<0.05$.

\section{Results}

Among 81 men with COVID-19, 86.42\% (70/81) were diagnosed as "moderate type", $8.64 \%(7 / 81)$ as "severe type" and $2.47 \%(2 / 81)$ as "critical type". The usages of corticosterone, arbidol, oseltamivir and intravenous antibiotics was 14.81\% (12/81), $44.44 \%(36 / 81), 33.33 \%(27 / 81)$ and $51.85 \%$ (42/81) respectively. $38.27 \%(31 / 81)$ of the patients had elevated serum alanine transaminase (ALT) and/or serum aspartate transaminase (AST), indicating the impaired liver function. The clinical characteristics of the patients were presented in Table 1.

Compared to the control group, COVID-19 patients had significantly higher serum 
LH $(\mathrm{p}<0.0001)$ and serum PRL $(\mathrm{p}<0.0001)$. Although there was no statistical difference in serum $\mathrm{T}(\mathrm{p}=0.0945)$ or FSH $(\mathrm{p}=0.5783)$ between the two groups, the ratios of T:LH $(\mathrm{p}<0.0001)$ and FSH: LH $(\mathrm{p}<0.0001)$ were dramatically decreased in the COVID-19 group (seen in Table 2).

In the control group, only 54 out of 100 men had the record of serum $E_{2}$. Since they were also age-matched with the COVID-19 patients, the comparison of $E_{2}$ or $T: E_{2}$ ratio was performed between them and the COVID-19 group. No significant difference was observed in either E2 or T: E2 ratio. (seen in Table 3)

By univariable linear regression analysis, it can be seen that serum T:LH ratio in the COVID-19 group was negatively associated with the severity $(\mathrm{p}=0.0236)$, aspartate transaminase $(\mathrm{AST})$ concentration $(\mathrm{p}=0.0287)$, and c-reactive protein $(\mathrm{CRP})$ level $(\mathrm{p}<0.0001)$, but positively associated with serum AMH level $(\mathrm{p}=0.0067)$. On multivariable analysis, only CRP level $(\mathrm{p}=0.0128)$ were significantly associated serum T:LH. (Seen in Table 4)

\section{Discussion}

There are accumulative evidences that male reproductive systems are vulnerable to virus infection. Unlike bacterial infections which usually invade accessory glands and epididymis, virus circulating in the blood mainly attack testis. It is known that a broad range of virus families, including human immunodeficiency virus (HIV), mumps virus, influenza, Zika virus, CoxsacKie virus, may induce orchitis and even result in male infertility ${ }^{[14]}$. Besides, many viruses such as Ebola, HIV, Zika and Hepatitis virus B/C can be transmitted into semen and cause sexual transmission. The deleterious effects of viruses involve the direct damage of spermatozoon, abnormal sex-hormone secretion, and dysregulation of inflammatory cytokines. For example, a study based on rams showed that bluetongue virus can replicate in the endothelial cells of the peritubular areas within the testes, leading to enhanced type-I interferon response, decreased testosterone biosynthesis by Leydig cells, and even destruction of Sertoli cells ${ }^{[15]}$.

The testes are mainly constructed by seminiferous tubules and intertubular tissue. The seminiferous tubules are the place where the sperm are generated, composed of 
sperm-producing cells (spermatogonia) and the supporting Sertoli cells. The interstitial Leydig cells are responsible for testosterone production under regulation of LH. It was reported that SARS-CoV-2 uses ACE2 and the cellular serine protease TMPRSS2 for entry into host cells ${ }^{[6]}$. Based on scRNA-seq analysis, Wang ZP et al. found that TMPRSS2 mainly exists in spermatogonia and spermatids, whereas ACE2 widely expresses in spermatogonia, Leydig and Sertoli cells. Gene ontology (GO) enrichment analysis further indicated that GO categories associated with viral reproduction and transmission were positively enriched in ACE2-positive spermatogonia ${ }^{[9]}$. SARS, the similar virus of SARS-CoV-2, has been reported to cause orchitis ${ }^{[13]}$. Taken together, we suppose that testes may also run high risk of damage and dysregulation under COVID-19.

Since the major roles of testes are spermatogenesis and androgens secretion, the sex-related steroids can be used to evaluate the status of male gonad. In order to learn the effect of SARS-CoV-2 infection on male reproductive function, we compared the sex hormone profiles between COVID-19 patients and age-matched healthy men with normal fertility in this study. Although serum testosterone levels did not statistically change in the COVID-19 group, a significant increase in serum LH level and a dramatic decrease in serum T: LH were observed. In interpreting those results, the following points should be taken into account: (1) As known, there is a subtle negative feedback between $\mathrm{T}$ in testes and LH in pituitary. In the early stage of hypogonadism, impaired T production may stimulate the release of $\mathrm{LH}$ which can maintain T level temporarily. (2) The basal T level in the population varies widely, thus the ratio between hormones, such as $\mathrm{T} / \mathrm{LH}$ or $\mathrm{T} / \mathrm{E} 2$, was considered as better parameters for male gonad function evaluation $^{[16-17]}$.

The serum PRL level also significantly elevated in COVID-19 patients. Since serum PRL can be influenced be multiple factors, such as diet, stress, drugs, etc., the elevation was not surprising. But it should be mentioned that high PRL level may lead to pituitary suppression and decreased gonadotropins ${ }^{[18]}$, while serum LH was increased in this study. Taken together, we infer that the elevated LH and decreased 
medRxiv preprint doi: https://doi.org/10.1101/2020.03.21.20037267; this version posted March 30, 2020. The copyright holder for this preprint (which was not certified by peer review) is the author/funder, who has granted medRxiv a license to display the preprint in It is made available under a CC-BY-NC-ND 4.0 International license .

T:LH ratio are more likely to be caused by testes dysfunction, such as the possible damage of Leydig cells.

Unlike serum LH level, serum FSH, serum E2 and the ratio of T: E2 were not significantly different between the COVID-19 group and the control group. In men, FSH is mainly suppressed by inhibin B secreted by Sertoli cells, and estradiol normally comes from peripheral aromatization of androgens. Therefore, it seemed that Sertoli cells were less disturbed than Leydig cells under COVID-19.

We also analyzed the relationship between serum T:LH and main clinical characteristics of the COVID-19 patients. Although higher rank of severity, elevated AST, increased CRP and AMH seemed to be associated with lower T:LH on univariable analysis, only CRP was significantly associated with T:LH ratio after adjustment on multivariable analysis. CRP is an acute-phase protein produced by the liver which rises in acute inflammation throughout the body. In COVID-19, rapid and dramatic increase of CRP was observed more often in severe cases than in non-severe cases ${ }^{[19]}$. In acute inflammation, elevated CRP are also accompanied with abnormal cytokines. And some cytokines, such as interferon, may affect testes function and spermatogenesis ${ }^{[20]}$.

This study has several strengths. The study provides the first evidence about the alteration of sex-related hormones under COVID-19. And we found serum LH significantly elevated and T: LH ratio decreased in COVID-19 patients, which infer to the potential hypogonadism. The percentage of non-severe cases (mild and moderate type) included in this study is $88 \%(72 / 81)$, which is consistent to what has been reported by a large retrospective study ${ }^{[20]}$. Since more than half of people with COVID19 were reproductive-aged ${ }^{[20]}$, more attention should be paid to the effect of SARSCoV-2 on reproductive system, and gonadal function evaluation including semen examination is necessary in the follow-up of those who recovered from COVID-19.

There are also some limitations in this study. First, neither semen parameters nor existence of SARS-CoV-2 in semen was detected, which are more straightforward evidence for testes injury caused by SARS-CoV-2. Second, due to the small size of samples, only 2 mild cases, 7 severe cases and 2 critical cases are included, which may affect the power of statistical analysis, such as the association between severity and 
medRxiv preprint doi: https://doi.org/10.1101/2020.03.21.20037267; this version posted March 30, 2020. The copyright holder for this preprint (which was not certified by peer review) is the author/funder, who has granted medRxiv a license to display the preprint in It is made available under a CC-BY-NC-ND 4.0 International license .

T:LH ratio. Third, in the condition of COVID-19, some other factors such as stress and corticosteroid therapy may also influence hypothalamic-pituitary-gonadal axis. However, it should be mentioned that corticosteroids are usually believed to impair LH release instead of promoting it as seen in this study ${ }^{[21,22]}$. In the end, repeated detection with appropriate time interval (such as 3 months or 6 months later) is necessary.

\section{Reference}

[1] Li, Q, Guan X, Wu P, et al. Early Transmission Dynamics in Wuhan, China, of Novel Coronavirus-Infected Pneumonia. N Engl J Med, 2020. Jan 29. doi: 10.1056/NEJMoa2001316.

[2] Gralinski, LE, Menachery VD. Return of the Coronavirus: 2019-nCoV. Viruses, 2020, 12(2). Jan 24;12(2). pii: E135. doi: 10.3390/v12020135.

[3] Xiaoqiang Chai, Longfei Hu, Yan Zhang, et al. Specific ACE2 Expression in Cholangiocytes May Cause Liver Damage After 2019-nCoV Infection. bioRxiv, 2020, doi: https://doi.org/10.1101/2020.02.03.931766

[4] Hao Zhang, Zijian Kang, Haiyi Gong, et al. The digestive system is a potential route of 2019-nCov infection: a bioinformatics analysis based on single-cell transcriptomes. bioRxiv, 2020.doi: https://doi.org/10.1101/2020.01.30. 927806

[5] Xin Zou, Ke Chen, Jiawei Zou, et al. (2020) The single cell RNA seq data analysis on the receptor ACE2 expression reveals the potential risk of different human organs vulnerable to Wuhan $2019 \mathrm{nCoV}$ infection. Front. Med, 2020, https://doi.org/10.1007/s11684-020-0754-0

[6] Markus Hoffmann, Hannah Kleine-Weber, Nadine Krüger, et al. The novel coronavirus 2019 (2019-nCoV) uses the SARS-coronavirus receptor ACE2 and the cellular protease TMPRSS2 for entry into target cells. bioRxiv, 2020, doi: https://doi.org/10.1101/2020.01.31.929042

[7] Yu Zhao, Zixian Zhao, Yujia Wang, et al. (2020) Single-cell RNA expression profiling of ACE2, the putative receptor of Wuhan 2019-nCov. bioRxiv, 2020, doi: https://doi.org/10.1101/2020.01.26.919985

[8] Cabin Fan, Kai Li, Yanhong Ding, et al. ACE2 Expression in Kidney and Testis May Cause Kidney and Testis Damage After 2019-nCoV Infection. MedRxiv, 2020, doi: https://doi.org/10.1101/2020.02.12.20022418

[9] Wang, Z., Xu, X. scRNA-seq Profiling of Human Testes Reveals the Presence of ACE2 Receptor, a Target for SARS-CoV-2 Infection, in Spermatogonia, Leydig and Sertoli Cells. Preprints 2020, 2020020299 (doi: 10.20944/preprints202002. 0299.v1).

[10]Li N, Wang T, Han D. Structural, cellular and molecular aspects of immune privilege in the testis. Front Immunol, 2012, 3:152. http://dx.doi.org/10.3389/ fimmu. 2012.00152

[11] Salam AP, Horby PW. The Breadth of Viruses in Human Semen. Send to Emerg Infect Dis. 2017 Nov;23(11):1922-1924. doi: 10.3201/eid2311.171049. 
medRxiv preprint doi: https://doi.org/10.1101/2020.03.21.20037267; this version posted March 30, 2020. The copyright holder for this preprint (which was not certified by peer review) is the author/funder, who has granted medRxiv a license to display the preprint in It is made available under a CC-BY-NC-ND 4.0 International license .

[12]Liu W, Han R, Wu H, Han D. Viral threat to male fertility. Andrologia, 2018, 50(11): e13140. doi: 10.1111/and.13140.

[13]Xu J, Qi L, Chi X, et al. Orchitis: a complication of severe acute respiratory syndrome (SARS). Biol Reprod, 2006, 74(2): p. 410-416.

[14] Weihua Liu, Ruiqin Han, Han Wu, et al. Viral threat to male fertility. Andrologia, 2018, 50(11): e13140. doi: 10.1111/and.13140

[15]Puggioni G, Pintus D, Melzi E, et al. Testicular degeneration and infertility following arbovirus infection. J Virol, 2018, 12;92(19). pii: e01131-18. doi: 10.1128/JVI.01131-18.

[16] Shuling L, Sie Kuei ML, Saffari SE, et al. Do men with normal testosteroneoestradiol ratios benefit from letrozole for the treatment of male infertility? Reprod Biomed Online, 2019, 38(1):39-45. doi: 10.1016/j.rbmo. 2018.09.016.

[17]Lardone MC 1, Piottante A, Valdevenito R, et al. Histological and hormonal testicular function in oligo/azoospermic infertile men. Andrologia, 2013 Dec;45(6):379-85. doi: 10.1111/and.12026.

[18]Brown RSE, Khant Aung Z, Phillipps HR, et al. Acute Suppression of LH Secretion by Prolactin in Female Mice Is Mediated by Kisspeptin Neurons in the Arcuate Nucleus. Endocrinology 2019, 160: 1323-1332. DOI:10.1210 /en.2019-00038

[19] Weijie Guan, Zhengyi Ni, Yu Hu, et al. Clinical characteristics of 2019 novel coronavirus infection in China. New England Journal of Medicine, 2020, doi: 10.1056/NEJMoa2002032

[20] Wassie T, Fanmei Z, Jiang X, et al. Recombinant B2L and Kisspeptin-54 DNA vaccine induces immunity against Orf virus and inhibits spermatogenesis in rats. Sci Rep, 2019, 9:16262. DOI:10.1038/s41598-019-52744-y

[21]Breen KM. Does cortisol inhibit pulsatile luteinizing hormone secretion at the hypothalamic or pituitary level? Endocrinology, 2004, 145: 692-698. DOI:10.1210 /en.2003-1114

[22] Kreisman M, McCosh R, Tian K, et al. Estradiol enables chronic corticosterone to inhibit pulsatile LH secretion and suppress Kiss 1 neuronal activation in female mice. Neuroendocrinology, 2019, 29. doi: 10.1159/000502978 
Table 1. Clinical characteristics of 81 male patients with COVID-19

\begin{tabular}{|c|c|}
\hline & COVID-19 patients, $\mathrm{N}=81$ \\
\hline Age, median $\left(25^{\text {th }} \sim 75^{\text {th }}\right.$ percentile $)-$ yrs & $38(34.5 \sim 42.5)$ \\
\hline \multicolumn{2}{|l|}{ Age group $(\%)$} \\
\hline$<30 \mathrm{yrs}$ & $8.64 \%(7 / 81)$ \\
\hline 30 39 yrs & $54.32 \%(44 / 81)$ \\
\hline $40 \sim 49$ yrs & $29.63 \%(24 / 81)$ \\
\hline$\geq 50 \mathrm{yrs}$ & $7.41 \%(6 / 81)$ \\
\hline \multicolumn{2}{|l|}{ Symptoms (\%) } \\
\hline fever & $96.30 \%(78 / 81)$ \\
\hline cough & $44.44 \%(36 / 81)$ \\
\hline Sore throat & $6.17 \%(5 / 81)$ \\
\hline Myalgia & $12.35 \%(10 / 81)$ \\
\hline Dyspnoea & $17.28 \%(14 / 81)$ \\
\hline Chest pain & $2.47 \%(2 / 81)$ \\
\hline Diarrhoea & $7.41 \%(6 / 81)$ \\
\hline Abnormal Chest CT (\%) & $97.53 \%(79 / 81)$ \\
\hline Corticosteroid Therapy (\%) & $14.81 \%(12 / 81)$ \\
\hline \multicolumn{2}{|l|}{ Laboratory characteristics (median, range) } \\
\hline White blood cell count $\left(\mathrm{WBC}, \times 10^{9} / \mathrm{L}\right)$ & $6.42(2.25 \sim 11.58)$ \\
\hline Lymphocyte count $\left(\mathrm{x} \quad 10^{9} / \mathrm{L}\right)$ & $1.88(0.22 \sim 3.77)$ \\
\hline C-reactive protein $(\mathrm{CRP}, \mathrm{mg} / \mathrm{L})$ & $1.10(0.50 \sim 48.27)$ \\
\hline Alanine transaminase (ALT, IU/L) & $43(13 \sim 799)$ \\
\hline Aspartate transaminase (AST, IU/L) & $23(12 \sim 453)$ \\
\hline Creatinine $(\mu \mathrm{mol} / \mathrm{L})$ & $74.9(39.7 \sim 122.0)$ \\
\hline Urea nitrogen $(\mathrm{mmol} / \mathrm{L})$ & $4.3(1.9 \sim 8.50)$ \\
\hline D-dimer $(\mathrm{mg} / \mathrm{L})$ & $0.22(0.10 \sim 7.00)$ \\
\hline
\end{tabular}


Table 2. Sex-related Hormone Profiles in COVID-19 group and the control group

\begin{tabular}{lccc}
\hline & $\begin{array}{c}\text { Men with COVID-19 } \\
(\mathrm{N}=81)\end{array}$ & $\begin{array}{c}\text { Age-matched healthy men } \\
(\mathrm{N}=100)\end{array}$ & $p$ value \\
\hline Age - yrs & $38(34.5 \sim 42.5)$ & $38(35 \sim 41)$ & 0.7021 \\
Testosterone $(\mathrm{ng} / \mathrm{mL})$ & $3.97(3.12 \sim 5.68)$ & $4.79(3.49 \sim 5.62)$ & 0.0945 \\
FSH $(\mathrm{mIU} / \mathrm{mL})$ & $4.13(3.02 \sim 6.31)$ & $4.51(3.39 \sim 5.97)$ & 0.5783 \\
LH $(\mathrm{mIU} / \mathrm{mL})$ & $5.93(4.31 \sim 8.25)$ & $3.28(2.48 \sim 4.61)$ & $<0.0001^{*}$ \\
PRL $(\mathrm{ng} / \mathrm{mL})$ & $24.07(18.76 \sim 31.15)$ & $7.82(5.92 \sim 11.22)$ & $<0.0001^{*}$ \\
& & $1.31(0.95 \sim 2.06)$ & $<0.0001^{*}$ \\
T / LH & $0.74(0.44 \sim 1.06)$ & $1.38(1.00 \sim 1.91)$ & $<0.0001^{*}$ \\
FSH / LH & $0.79(0.51 \sim 1.01)$ & N/A & N/A \\
AMH (ng/mL) & $6.20(4.21 \sim 9.59)$ & &
\end{tabular}

Data are presented as medians $\left(25^{\text {th }} \sim 75^{\text {th }}\right.$ percentile).

* statistically significant 
Table 3. Serum Estradiol (E2) and T: E2 ratio in COVID-19 paitents and the age-matched healthy men

\begin{tabular}{lccc}
\hline & $\begin{array}{c}\text { Men with COVID-19 } \\
(\mathrm{N}=81)\end{array}$ & $\begin{array}{c}\text { Age-matched healthy men* } \\
(\mathrm{N}=54)\end{array}$ & $p$ value \\
\hline Age (year) & $38.00(34.50 \sim 42.50)$ & $38.5(36.0 \sim 44.25)$ & 0.6896 \\
Estradiol $(\mathrm{pg} / \mathrm{mL})$ & $32.34(27.06 \sim 41.55)$ & $33.00(23.75 \sim 38.00)$ & 0.3183 \\
T/ E2 & $0.12(0.10 \sim 0.15)$ & $0.14(0.10 \sim 0.18)$ & 0.1340 \\
\hline
\end{tabular}

* Only 54 out of 100 in the control group had the record of serum estradiol. Since they are also age-matched with the COVID-19 group, they are used as the control group for E2 and T: E2 comparison.

Data are presented as medians $\left(25^{\text {th }} \sim 75^{\text {th }}\right.$ percentile $)$. 
Table 4. Linear regression for association of clinical characteristics of COVID-19 patients with serum T:LH ratio

\begin{tabular}{llccccc}
\hline & \multicolumn{3}{c}{ Univariable analysis } & \multicolumn{3}{c}{ Multivariable analysis } \\
& \multicolumn{2}{c}{$95 \%$ CI (slope) } & $p$ value & \multicolumn{2}{c}{$95 \%$ CI } & $p$ value \\
\hline Severity $\dagger$ & -0.4564 & -0.0338 & 0.0236 & -0.2515 & 0.1719 & 0.7083 \\
$\mathrm{AST}(\mathrm{IU} / \mathrm{L})$ & -63.65 & -3.593 & 0.0287 & -0.0017 & 0.0014 & 0.8864 \\
$\mathrm{CRP}(\mathrm{mg} / \mathrm{L})$ & -15.71 & -6.020 & $<0.0001$ & -0.0281 & -0.0035 & $0.0128^{*}$ \\
$\mathrm{AMH}(\mathrm{ng} / \mathrm{mL})$ & 0.7733 & 4.656 & 0.0067 & -0.0093 & 0.0393 & 0.2233 \\
\hline
\end{tabular}

Only the variables showing statistical significance in univariable analysis were included in the multivariable analysis. 95\% CI: 95\% confidence interval

* statistically significant

$\dagger$ severity: 1- mild type, 2-moderate type, 3-severe type, 4-critical type 